\title{
Pelatihan Pengembangan Sumberdaya Manusia (PSDM) Unsur Perangkat Desa Dan Kader Pembangunan Manusia Se-Kecamatan Aikmel Kabupaten Lombok (Stunting Dan Konvergensi Pencegahan Stunting)
}

\author{
Khosiah $^{1}$ dan Sintayana Muhardini ${ }^{2}$ \\ Universitas Muhammadiyah Mataram \\ osynasdem01@gmail.com
}

\begin{abstract}
Abstrak
Stunting adalah kondisi gagal tumbuh pada anak balita akibat kekurangan gizi kronis terutama pada 1.000 Hari Pertama Kehidupan (HPK). Stunting mempengaruhi pertumbuhan dan perkembangan otak. Anak stunting juga memiliki risiko lebih tinggi menderita penyakit kronis di masa dewasanya. Bahkan, stunting dan malnutrisi diperkirakan berkontribusi pada berkurangnya 23\% Produk Domestik Bruto (PDB) setiap tahunnya. Berdasarkan hasil Riset Kesehatan Dasar (Riskesdas) Tahun 2018 menunjukkan bahwa terdapat data 30,8\% atau terdapat 7 Juta anak Indonesia terkena stunting. Hal ini merupakan permasalahan yang serius sehingga pemerintah dengan serius dalam penanganan dan pencegahan masalah stunting tersebut. Sejalan dengan Peraturan Menteri Desa, Pembangunan Daerah Tertinggal dan Transmigrasi No.16 Tahun 2018 bahwa salah satu prioritas penggunaan Dana Desa itu adalah salah satunya diperuntukkan untuk penanganan stunting melalui pelayanan kesehatan dan gizi. Penurunan stunting memerlukan intervensi yang terpadu, mencakup intervensi gizi spesifik dan gizi sensitif. Metode yang digunakan dalam pelatihan ini adalah metode ceramah, metode tanya jawab dan metode diskusi, metode dokumentasi. Berdasarkan hasil pelatihan menunjukkan bahwa para kader pembangunan manusia (KPM) sudah mampu memahami permasalahan stunting dan upaya pencegahan dan penanganan stunting.
\end{abstract}

\section{Kata Kunci : Stunting, Konvergensi Stunting, Pencegahan stunting}

\section{PENDAHULUAN}

Paradigma pembangunan Desa pada saat ini diwarnai oleh pendekatan pemberdayaan masyarakat utamanya menempatan masyarakat desa sebagai subjek pembangunan. Undang-Undang Desa yang mengamanhkan bahwa salah satu tujuan peraturan desa adalah memperkuat masyarakat desa sebagai sebagai subjek pembangunan. Selain itu Undang-Undang Desa juga mengamnahkan bahwa tujuan dari pembangunan desa yakni meliputi peningkatan kualitas hidup manusia, meningkatkan kesejahteraan masyarakat dan menanggulangi kemiskinan. Oleh sebab itu pada era implementasi Undang-Undang Desa kegiatan pelayanan sosial dasar utamanya pembangunan dibidang kesehatan dan pendidikan menjadi sangat penting.

Pembangunan kesehatan di Desa diarahkan pada pengutamaan upaya peningkatan pencegahan penyakit (Preventif) dan peningkatan promosi kesehatan (Promotif). Namun demikan tanpa mengasingkan terutama dalam upaya meninkatkan derajat kesehatan masyarakat dilakukan pengobatan penyakit (Kuratif) dan upaya pemulihan kesehatan (Rehabilitatif) utamanya bagi masyarakat yang kurang mampu atau miskin. Pembangunan kesehatan di Desa harus dilakukan secara terpadu, terintegrasi dan berkesinambungan dengan menayagunakan potensi sumberdaya maupun layanan kesehatan yang tersedia di Desa.

Stunting adalah kondisi gagal tumbuh pada anak balita akibat kekurangan gizi kronis terutama pada 1.000 Hari Pertama Kehidupan (HPK). Kondisi gagal tumbuh pada anak balita disebabkan oleh kurangnya asupan gizi dalam waktu lama serta terjadinya infeksi berulang, dan kedua faktor penyebab ini dipengaruhi oleh pola asuh yang tidak memadai terutama dalam 1.000 HPK. Anak tergolong stunting apabila panjang atau tinggi 
badan menurut umurnya lebih rendah dari standar nasional yang berlaku. Standar dimaksud terdapat pada buku Kesehatan Ibu dan Anak (KIA) dan beberapa dokumen lainnya.

Penurunan stunting penting dilakukan sedini mungkin untuk menghindari dampak jangka panjang yang merugikan seperti terhambatnya tumbuh kembang anak. Stunting mempengaruhi perkembangan otak sehingga tingkat kecerdasan anak tidak maksimal. Hal ini berisiko menurunkan produktivitas pada saat dewasa. Stunting juga menjadikan anak lebih rentan terhadap penyakit. Anak stunting berisiko lebih tinggi menderita penyakit kronis di masa dewasanya. Bahkan, stunting dan berbagai bentuk masalah gizi diperkirakan berkontribusi pada hilangnya 23\% Produk Domestik Bruto (PDB) setiap tahunnya.

Riset Kesehatan Dasar (Riskesdas) Kementerian Kesehatan pada 2018 menemukan 30,8\% atau sekitar 7 juta anak balita mengalami stunting. Mengacu pada "The Conceptual Framework of the Determinants of Child Undernutrition", "The Underlying Drivers of Malnutrition", , dan "Faktor Penyebab Masalah Gizi Konteks Indonesia" penyebab langsung masalah gizi pada anak termasuk stunting adalah rendahnya asupan gizi dan status kesehatan. Penurunan stunting menitikberatkan pada penanganan penyebab masalah gizi, yaitu faktor yang berhubungan dengan ketahanan pangan khususnya akses terhadap pangan bergizi (makanan), lingkungan sosial yang terkait dengan praktik pemberian makanan bayi dan anak (pengasuhan), akses terhadap pelayanan kesehatan untuk pencegahan dan pengobatan (kesehatan), serta kesehatan lingkungan yang meliputi tersedianya sarana air bersih dan sanitasi (lingkungan). Keempat faktor tersebut mempengaruhi asupan gizi dan status kesehatan ibu dan anak. Intervensi terhadap keempat faktor tersebut diharapkan dapat mencegah masalah gizi, baik kekurangan maupun kelebihan gizi.

\section{A. Tujuan}

Adapun tujuan diadakannya pelatihan ini adalah:

1. Untuk meningkatkan kapasitas kader pembangunan manusia (KPM)

2. Meningkatkan peran Kader Pembangunan Manusia (KPM) yang terdidik dan terlatih untuk mewujudkan konvergensi layanan kesehatan di Desa, utamanya konvergensi pencegahan stunting di Desa.

\section{B. Manfaat}

Adapun manfaat dari pelaksanaan pelatihan ini adalah :

1. Sebagai pedoman bagi Kader Pembangunan Manusia (KPM) dan Pemerintah Desa dalam memfasilitasi pembentukan dan pengelolaan Rumah Desa Sehat di Desa.

2. Mendayagunakan Rumah Desa Sehat) RDS sebagai Sekretariat Bersama bagi para pegiat pemberdayaan masyarakat dan pelaku pembangunan di Desa khususnya yang bergerak di bidang kesehatan untuk mempercepat konvergensi pencegahan stunting.

\section{Dasar Hukum}

1. Undang-Undang Republik Indonesia Nomor 40 Tahun 2004 tentang Sistem Jaminan Sosial Nasional;

2. Undang-Undang Republik Indonesia Nomor 36 Tahun 2009 tentang Kesehatan;

3. Undang-Undang Republik Indonesia Nomor 6 Tahun 2014 tentang Desa;

4. Undang-Undang Republik Indonesia Nomor 2 Tahun 2015tentang Penetapan Peraturan Pemerintah Pengganti UndangUndang Nomor 2 Tahun 2014 tentang Perubahan Atas Undang-Undang Nomor 23 Tahun 2014 tentang Pemerintah Daerah Menjadi Undang-Undang;

5. Peraturan Pemerintah Republik Indonesia Nomor 47 Tahun 2015 tentang Perubahan Peraturan Pemerintah Nomor 43 Tahun 2014 tentang Peraturan Pelaksanaan Undang- Undang Nomor 6 Tahun 2014 tentang Desa;

6. Peraturan Pemerintah Republik Indonesia Nomor 22 Tahun 2015 tentang Perubahan Atas Peraturan Pemerintah Nomor 60 Tahun 2014 tentang Dana Desa Yang 
Bersumber Dari Anggaran Pendapatan Dan Belanja Negara;

7. Peraturan Pemerintah Republik Indonesia Nomor 2 Tahun 2018 tentang Standar Pelayanan Minimal;

8. Peraturan Pemerintah Republik Indonesia

9. Peraturan Presiden Republik Indonesia Nomor 72 Tahun 2012 tentang Sistem Kesehatan Nasional; 10. Peraturan Presiden Republik Indonesia Nomor 42 Tahun 2013 tentang Gerakan Nasional Percepatan Perbaikan Gizi;

10. Peraturan Presiden Republik Indonesia Nomor 60 Tahun 2013 tentang Pengembangan anak Usia Dini Holistik Intergratif.

11. Peraturan Presiden Republik Indonesia Nomor 111 Tahun 2013 tentang Perubahan atas Peraturan Presiden Nomor 12 Tahun 2013 tentang Jaminan Kesehatan;

12. Peraturan Presiden Republik Indonesia Nomor 2 Tahun 2015 tentang RPJMN 2015-2019;

13. Instruksi Presiden Nomor 5 tahun 2014 tentang Gerakan Nasional Anti Kejahatan Seksual terhadap Anak.

14. Instruksi Presiden Nomor 1 tahun 2017 tentang Gerakan Masyarakat Hidup Sehat.

15. Peraturan Menteri Dalam Negeri Republik Indonesia Nomor 19 Tahun 2011 tentang Pedoman Pengintegrasian Layanan Sosial Dasar di Pos Pelayanan Terpadu;

16. Peraturan Menteri Dalam Negeri Republik Indonesia Nomor 44 Tahun 2016 tentang Kewenangan Desa.

\section{METODE PELAKSANAAN}

Metode merupakan cara yang dilakukan dalam melakukan kegiatan pelatihan supaya kegiatan pelatihan lebih terarah. Adapun metode yang dilakukan dalam pelatihan ini yakni :

1. Metode Ceramah

Metode ceramah adalah penyajian informasi secara lisan baik yang formal maupun informal. Metode ceramah ini dilakukan untuk menjelaskan materi kepada para peserta pelatihan kaitannya dengan bagaimana memetakan kondisi sosial masyarakat serta bagaimana mendata stunting sesuai dengan acuan 5 paket layananan.
2. Metode Tanya Jawab dan Diskusi

Metode diskusi merupakan suatu metode pengajaran dimana para pelatih menjelskan suatu persoalan stunting kepada peserta pelatihan yang kemudian sama-sama dibahas untuk mencari solusi permasalahnnya serta dalam metode diskusi ini para peserta pelatihan bisa mengemukakan permasalahan yang dialami di desa masing-masing mengenai kondisi masyarakat untuk dibahas dan dicari solusinya.

\section{Metode Dokumentasi}

Metode dokumentasi adalah salah satu metode pengumpulan data kualitatif dengan melihat atau menganalisis dokumen yang sudah dibuat.

Jadi dalam pelatihan ini mendokumentasikan segala kegiatan yang dilakukan oleh pelatih dan para peserta pelatihan

\section{E. PENYELENGGARAAN KEGIATAN}

\section{Waktu dan Tempat Kegiatan}

Waktu pelaksanan pelatihan yakni sebelum Musyawarah Perencanaan Pembangunan Desa (Musrenbangdes) atau pengesahan Rencana Kegiatan Pembangunan Desa (RKPDes). Adapun tempat pelaksanaan kegiatan yakni di Aula Kantor Camat Aikmel. Peserta dalam pelatihan ini adalah para Kader Pembangunan Manusia (KPM) dan Pemerintah Desa yang dalam hal ini diwakili oleh Kasi Kesejahteraan yang membidangi bidang kesehatan.

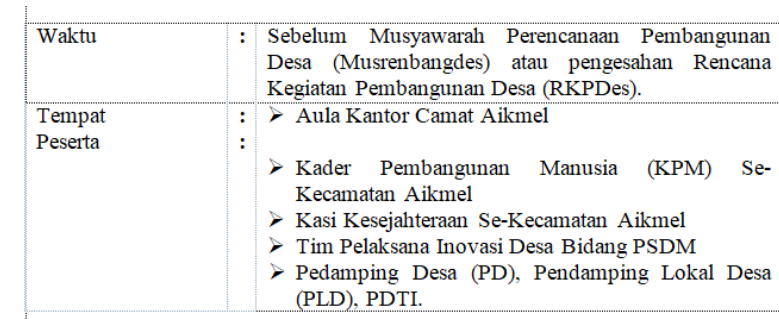

\section{Hasil Kegiatan}

Adapun data peserta Pelatihan Pengembangan Sumberdaya Manusia dari Unsur Kader Pembangunan Manusia (KPM) dan Kasi Kesejahteraan Se-Kecamatan 
Aikmel yakni dapat dilihat pada Tabel berikut.

Tabel 01. Data KPM Se-Kecamatan Aikmel

\begin{tabular}{|l|l|l}
\hline \multicolumn{1}{|c}{ Tabel 01 . Data KPM Se-Kecamatan Aikmel } \\
\hline NO. & \multicolumn{1}{|c}{ NAMA KPM } & \\
\hline 1 & EVA SARI SUDIYATNI & AIKMEL \\
\hline 2 & PATHUL JANNAH & AIKMEL TIMUR \\
\hline 3 & YUSNIA HERAWATI & AIKMEL BARAT \\
\hline 4 & SAOPIAH & AIKMEL UTARA \\
\hline 5 & ZOHRATUDDIANA & BAGEK NYAKA SANTRI \\
\hline 6 & ISPAN & KALIJAGA \\
\hline 7 & INDRAYATI & KALIJAGA TENGAH \\
\hline 8 & SUHAII,S.S & KALIJAGA SELATAN \\
\hline 9 & MARYANI,A.Ma & KALIJAGA TIMUR \\
\hline 10 & NURYANI, S.Pd & TOYA \\
\hline 11 & BAIQ DEWI SINTA ASNAWATI & AIKPRAPA \\
\hline 12 & JOHARIAH & KEROYA \\
\hline 13 & HAERIAH & KEMBANGKERANG \\
\hline 14 & MUSTA'AN, S.Pd & KEMBANGKERANG DAYA \\
\hline (Sumber : Olahan, 2019) &
\end{tabular}

Tabel 02. Data Kasi Kesejahteraan Se-Kecamatan Aikmel

\begin{tabular}{|l|l|l}
\hline NO. & \multicolumn{1}{|c|}{ NAMA KASI KESRA } & ALA \\
\hline 1 & WIWIN HASPIANTI & AIKMEL BARAT \\
\hline 2 & H.SUHARNI & KEROYA \\
\hline 3 & MISRUN & AIKMEL TIMUR \\
\hline 4 & MUHSININ & KEMBANGKERANG \\
\hline 5 & RABIATUL ADAWIYAH & AIKMEL \\
\hline 6 & JAMIL ULAN & BAGEK NYAKA SANTI \\
\hline 7 & MUH. AFANDI & AIKPRAPA \\
\hline 8 & ERLINA ANUGRAHANI & AIKMEL UTARA \\
\hline 9 & NISTIAWATI LAILY & TOYA \\
\hline 10 & MAAD & KALIJAGA TENGAH \\
\hline 11 & MUSTAPID & KALIJAGA \\
\hline 12 & NURJANNAH & KEMBANGKERANG D \\
\hline 13 & TAKIAH & KALIJAGA SELATAN \\
\hline 14 & PAUZIAH, S.Sos & KALIJAGA TIMUR \\
\hline
\end{tabular}

(Sumber : Olahan, 2019)

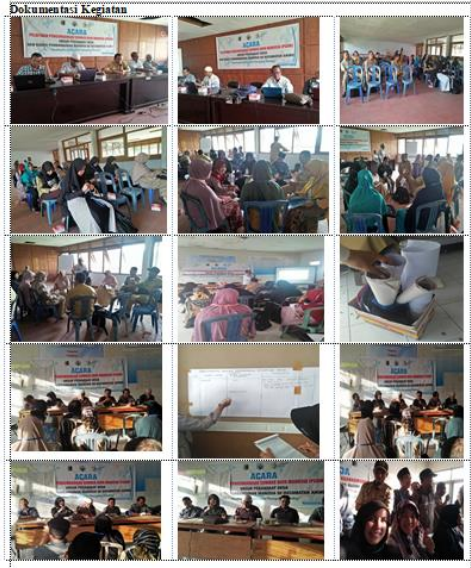

\section{Pembahasan}

Dalam pelatihan yang kami dilakukan Tim Pelaksana Inovasi Desa (TPID) Kecamatan Aikmel menghimbau kepada seluruh peserta supaya bener-bener serius dalam mengikuti materi pelatihan. Adapun dalam melaksanakan tugasnya dalam hal pencegahan stunting di Desa, KPM harus selalu berkoordinasi dengan pemerintah Desa. Berikut beberapa tugas dari Kader Pembangunan Manusia (KPM) yang nantinya akan melaksanakan fungsinya, antara lain:

1. Mensosialisasikan kebijakan konvergensi pencegahan stunting di Desa kepada masyarakat di Desa termasuk memperkienalkan tikar pertumbuhan untuk pengukuran panjang/tinggi badan Baduta sebagai alat deteksi dini stunting

2. Mendata sasaran rumah tangga 1000 HPK

3. Memantau layanan pencegahan stnting terhadap sasaran rumah tangga 1000 HPK untuk memastikan setiap sasaran pencegahan stunting mendapatkan layanan yang berkualitas.

4. Memfasilitasi dan mengadvokasi peningkatan belanja APBDES utamanya yang bersumber dari Dana Desa, untuk digunakan membiayai kegiatan pencegahan stunting berupa layanan intervensi gizi spesifik dan sensitif.

5. Menfasilitasi suami ibu hamil dan bapak dari anak usia 0-23 bulan untuk mengikuti kegiatan konseling gizi serta kesehatan ibu dan anak 
6. Menfasilitasi masyarakat Desa untuk berpartisipasi aktif dalam perencnaan, pelaksanaan dan pengawasan program/kgiatan pembangnan Desa untuk pemenuhan layanan gizi spesifik dan sensitif.

7. Melksanakan koordinasi dan/atau kerjasama dengan para pihak yang berperan serta dalam pelayanan pencegahan stunting seperti Bidan desa, petugas Puskesmas (ahli gizi, sanitarian) gru PAUD dan/atau perangkat Desa.

8. Segera melakukan musywarah pembentukan Rumah Desa Sehat

9. Setelah kepengurusan RDS terbentuk, supaya segera melakukan Fokus Grup discussion (FGD) terkait dengan hasil pendataan 1000 HPK yang dilakukan.

10. Hasil FGD yng telah dilaksanakan selanjutnya akan dibahas dalam Musyawarah rembuk Stunting, yang mana hasil dari musyawarah rembuk stunting inilah yang akan dijadikan acuan oleh Tim Penyusun RKPDes untuk di masukkan dalam RKPDes.

\section{F. PENUTUP}

\section{Simpulan}

Berdasarkan hasil Riset Kesehatan Dasar (Riskesdas) tahun 2018 yang sudah dilakukan tercatat $30,8 \%$ atau sekitar balita menderita stunting. Artinya tercatat sebanyak 7 juta balita di Indonesia yang saat ini merupakan generasi bangsa terancam kurang memiliki daya saing di masa depan. Peneceahan stunting sangat dibutuhkan untuk memastikan generasi muda Indonesia memiliki masa depan yang cerah. Menteri Desa, Pembangunan Daerah Tertinggal dn Transmigrasi telah menetapkan bahwa prioritas penggunaan Dana Desa Tahun 2019 adalah salah satunya untuk penanganan stunting. Sehingga dengan adanya pelatihan bagi KPM dan Pemerintah Desa yang dalam hal ini diwakili oleh kasi KESRA diharapkan Pemerintah Desa akan lebih terarah dalam mengalokasikan Dana Desa yang 20\% dalam penangan stunting.

\section{Saran}

1. Perlu adanya perhatian khusus dari Desa terhadap keberadaan KPM mengingat tugas yang diemban oleh KPM begitu banyak.

2. Perlu pelatihan-pelatihan tindak lanjut kaitannya dengan penanganan stunting, mengingat tidak semua KPM memiliki kemampuan yang sama dengan KPM yang lainnya.

\section{G. Daftar Pustaka}

Sardjoko, Subandi. 2018. Pedoman Pelaksanaan Intervensi Penurunan Stunting Terintegrasi di Kabupaten Kota. Jakarta : Deputi Bidang Pembangunan Manusia, Masyarakat dan Kebudayaan/ Bappenas. 